\title{
ホワイトカラーの二重コミットメントが業績と 転職意志に及ぼす影響
}

一コミットメントによる人材タイプ別の比較—

\begin{abstract}
慶應義塾大学 申 美 花
The Impact of Dual Commitment on Job Performance and Turnover Intention: Comparisons of Different Types White-collar Workers

Meehwa SHIN

(Keio University)

It is argued that white-collar workers are committed more heavily to their professions than to their employment organizations. This study classifies types of commitments among white-collar workers as 'professional', 'organizational' and 'dual' commitment. Based on samples of 180 white-collar workers, the research found that: (1) Specialty of the job and career development have an impact on job performance, however organizational, professional and dual commitment have no impact on job performance. (2) Extrinsic satisfaction factors ( payment, management policy, career path progress) influence the turnover intention, causing it to decline. Organizational and dual commitment similarly influence the decline in turnover intention, but professional commitment has no impact on the turnover intention.
\end{abstract}

\section{問題意識}

企業で働くホワイトカラーを大きく分けると事務系従 業員 (営業, マーケティング, 財務, 経理, 経営企画な ど）之研究開発従事者（研究者, 技術者）に分けられる。 この両者は, 組織内での位置付けと役割, 仕事内容も異 なり，それに価值観・目的や志向，コミットメントの対 象においてかなり異なる側面をあつ。事務系ホワイトカ ラーはいわゆる「組織人」として括られることが多く, 従来の研究ではいかにして事務系ホワイトカラーの組織 コミットメントを高め, 企業の業績をあげていくかとい うことについて実証研究が集中してきた。一方，研究開 発系ホワイトカラーは専門的知識と技術を備えたいわゆ る「プロフェッショナル」として扱われ，いかにしてプ ロフェッショナル・コミットメントを高め, 研究成果を 上げていくかについて実証研究が行われてきた。

本論文で焦点を当てる対象は, 従来組織人と呼ばれた

電子メール連絡先 : cfx89310@nyc.odn.ne.jp
事務系ホワイトカラーであり，いかにして彼らのプロフェッ ショナル化を進めることができるかが本論文のテーマで ある。過去における日本経済の高度成長と日本的経営は, 個々の社員から組織に対する膨大なコミットメントを調 達できたことによって成り立っていた（田尾他，1997）。 しかし, 情報技術の発達や国際化の急速の進展, 顧客二ズの多様化, 事業の高度化や専門化など企業を取り巻く 環境の変化に伴い, 日本的経営は有効性を失いつつある。 従って, 多くの研究者が組織人育成からプロフェッショ ナル人材育成の必要性を主張し, 組織へのコミットメン トからプロフェッショナル・コミットメントへという重 点の移行の必要性を指摘している（太田，1993; 石倉， 1995; 富士ゼロックス総合教育研究所, 1997 ; ニッセイ 基礎研究所, 2000)。

経営環境の変化により事務系ホワイトカラーに個人の 自律, 専門化, 創造性, 組織の枠を越えたキャリアの形 成が要請されるとしても，プロフェッショナル・コミッ トメントだけを求めるには, 次のような二つの問題点が 挙げられる。一つ目は, プロフェッショナル・コミット 
メントが高くなると, 組織に対して必要な範囲でしか貢 献しなくなり, その結果, 従来の日本企業の事務系ホワ イトカラーの強みである総合的な組織力として蓄積させ ていくことができなくなる点である。二つ目は, 専門家 社会の高い評価を受けるため, 狭い範囲での専門性を追 求することによって, 組織全体の目標やビジョンを共有 し，戦略や方向性を見極め，それを達成しようとする能 力に欠けてしまう恐れがある。特に, 事務系ホワイトカ ラーに欠かせない他の部署との調整役, リーダーシップ の発揮, 変化に対応できる柔軟性などが，欠如する可能 性が大きい。したがって, 事務系ホワイトカラーに求め られるのは，個人の創造性と高い専門性の発揮であり， 同時に組織目標の達成に向けたコミットメントである。 つまり, 従来要求されなかったプロフェッショナル・コ ミットメントが新たに求められるとともに，今までのよ うな高い組織コミットメントをそのまま維持されること が要求される。言い換えれば, 事務系ホワイトカラーに 求められる二重コミットメントが重要な経営課題となっ てきていることを意味するあのである。それにもかかわ らず，事務系ホワイトカラーの二重コミットメントの問 題についての実証分析は少なく, 研究の蓄積も十分に進 んでいるわけではない。

組織コミットメント (Organizational commitment）については, 数多くの調査研究が絽り返され, それに関する研究業績も相当量蓄積されている。組織コ ミットメントそのあのをどのように捉えるかについて, Porter, Steers, Mowday \& Boulian (1974) は, 「特定の組織に対する個人の一体化と関与の強さ」と定 義している。それは三つの構成要素, すなわち, (1) 組 織の目標・価値観の受容とそれに対する強い信念，(2) 組織のために進んで努力したい意志，(3) 組織成員性を 維持したいという願望から成り立つと主張し，OCQ (Organizational Commitment Questionnaire) と いう組織コミットメントの測定尺度を最初に開発した。 その後, OCQは, 多くの研究者によって測定尺度とし て信頼性と妥当性が立証され, 極めて広範囲に用いられ てきた。その後, O’Reilly \& Chatman（1986）は，組 織コミットメントの尺度として, 組織に対する心理的愛 着 (psychological attachment) をべースとし, 価值 の内在化 (internalization), 一体化 (identification), 服従 (compliance) の三次元で捉えることを提唱して いる。また, Allen \& Meyer（1990）は, Porter らの 研究での三つの構成要素が心理的愛着のみであると批判 し, 組織コミットメントの構成要素として情緒的要素 (affective), 継続的要素 (continuance), 規範的要素 (normative) の三つを挙げている。
過去の研究成果から得られた組織コミットメントの規 定要因は多様であり，Wiener（1982）が分類したよう に, 個人側の要因, 組織側の要因, そして個人と組織の 適合要因の 3 カテゴリーに分類することができる。第 1 に個人側の要因として多くの研究者が取り上げ, 一貫し た結果が得られたのは，年齢（Lee，1971; Steers， 1977; Stevens, Beyer \& Trice, 1978; 城戸, 1980; 若 林,1986; 高木 - 石田・益田, 1997), 勤続年数（Lee, 1971; 城戸, 1980; 花田, 1980; 高木・石田・益田, 1997; Beck \& Wilson, 2000), 成長欲求の強さ (Steers, 1977; Mathieu \& Hamel, 1989）である。研究結果の ほとんどが年龄と勤続年数が高まれば，また成長欲求が 強ければ, 組織コミットメントも高まることを明らかに している。年齢と勤続年数は，個人の組織への投資と関 係があり，投資した時間と努力が報われるかぎり，コミッ トメントは時間とともに高まるからである。また，成長 欲求をむつ個人が組織に参加し, 自らの役割のなかでそ れらの欲求を満たすことができれば，組織コミットメン トがより高まる可能性が大きくなるに違いない。第 2 に 組織側の要因として，職務特性（Steers， 1977; Mathieu \& Zajac, 1990; Dunham, Grube \& Castaneda, 1994), 職務満足（Porter, Steers, Mowday \& Boulian, 1974; Mathieu \& Hamel, 1989; 城戸, 1980; 高木・石田・益田, 1997), 役割の状態 (Morris \& Sherman, 1981; Mathieu \& Zajac, 1990; 高木・石田・益田，1997）が取り上げられてきた。 Hackman \& Oldham（1976）の職務特性モデルを利 用し実証研究した結果は, 職務の特性において自律性が 与えられ, 仕事が重要であり, 仕事との一体性を持ち, 技術が多様で, フィードバックが行われば，組織コミッ トメントは高まるということがこれまでの研究から明ら かになっている（Steers, 1977, pp.51-52, Mathieu \& Zajac, 1990, p.179, Dunham, Grube \& Castaneda, 1994, pp.374-376)。このことは, 組織が, 極めて重要 であり，チャレンジできる豊富な内容の仕事を提供する と，その交換として個人は組織に対して大きなコミット メントを示すということである。職務満足については, 組織コミットメントと類似した概念であることああり, ぞちらが先行要因であるのかについてこれまで多くの研 究で論じられてきた。しかし, 今のところ, 職務の満足 度が組織コミットメントの先行要因であるという立場を 支持する研究の方が多い上うである。その理由は，仕事 にかかわる環境についての満足度が時間的に早く形成さ れ, 組織全体へのコミットメントが時間的に長く安定し て形成されるからである。すなわち, 全般的な満足, 仕 事自体への満足, 昇進機会への満足, 同僚への満足, 上 
司への満足, 給与の満足が高くなれば, Maslow （1954）のいう人間の低次元と高次元の欲求が満たされ るにつれ，組織へのコミットメントも高くなると考えら れる。さらに，役割の葛藤や曖昧さが高くなると組織コ ミットメントは低くなるという研究結果む得られている (Mathieu \& Zajac, 1990, p.180, Morris \& Sherman, 1981, p.519, 高木・石田・益田, 1997, pp.287-289)。こ れは, 個人が複数の矛盾した要求の下で働いたり, 個人 に何が期待されているかわからなかったりすると, 次第 にコミットメントが下がることからであることを意味す る。第 3 に組織と個人の適合要因としては, 期待の充足 度 (Steers, 1977), 組織における個人の重要性（Buch anan, 1974; Steers, 1977）が取り上げられてきた。組 織に入って個人の期待が充足されれば組織コミットメン トは高まるし, また個人が組織にとって重要性を感じた とき, 組織コミットメントは高まることが指摘されたの である (Buchanan, 1974, pp.542-543, Steers, 1977, pp.51-52)。その理由は, 組織が個人の屯つ期待に応え, あるいは組織にとって個人が重要であり, 必要とされて いると認知しているとき, 組織のために報いようとし, コミットメントが高まるからである。

組織コミットメントを高めることが結果的に何をもた らすか。組織コミットメントの結果として多くの研究者 が取り上げていることは, 業績, 定着意志, 組織市民行 動といった組織効率と関わる変数である。既存の研究で 共通に表れる結果は, 組織コミットメントが高いほど, 業績も高くなり（Lee, 1971; Mowday, Porter \& Dubin, 1974; Mowday, Steers \& Porter, 1979), 離 • 転職意志は低くなり（Porter, Steers, Mowday \& Boulian, 1974; Porter, Crampon \& Smith, 1976; Steers, 1977; O’ Reilly \& Caldwell, 1981), 組織市民 行動をとるようになる（O' Reilly \& Chatman, 1986; Morrison, 1994; 西田, 2000）ことである。その理由と して, まず業績に関しては, 組織コミットメント定義自 体が組織のために意欲的に㗢き, 積極的に貢献をしたい という動機づけの側面をあっているからである。また,

転職意志との関わりとしても, 組織コミットメントが個 人に安心感や所属感をむたらし, 組織の成員性を維持し たくなるからである。つまり,コミットメントが低下す ると, 社員がますなく組織を離れることの指標となる。 つぎに, 組織コミットメントが高い人は, 自分に与えら れた職務上の役割以外に, 自ら進んで組織を手助けしょ うとする気持が含まれていることから，組織市民行動を とることで組織に貢献しようとするあのとして考えられ る。
しかし, 組織コミットメントと業績の関連については, 有意な関係を見出せなかった研究も多く存在している (Brett, Corn \& Slocum, 1995; Steers, 1977; Mathieu \& Zajac, 1990) ので, 必ずしも一貫した結果が示され てはいない。その理由の一つに, 業績の測定の難しさが あげられる。

プロフェッショナル・コミットメント（professional commitment) の研究は, 組織コミットメント の研究と比べると量は少ないものの, 近年特に注目を集 めている。プロフェッショナル・コミットメントとは, 専門分野 (例えば, 会計, 研究・技術, コンピュー夕な ど）に対する個人の一体化と関与の強さとして定義づけ られ (Aranya, Pollock \& Amernic, 1981, pp.271272, Aranya \& Ferris, 1984, p.3, Morrow \& Writh, 1989, p.40)，その測定尺度としては, Porter, Steers, Mowday \& Boulian (1974) の組織コミットメントを 測る尺度である OCQを, 対象だけ組織から専門分野に 変え，そのまま研究者によって使われてきた (Aranya, Pollock \& Amernic, 1981; Aranya \& Ferris, 1984; Lachman \& Aranya, 1986; Morrow \& Wirth, 1989)。

プロフェッショナル・コミットメントを高める要因と して, 個人側の要因と組織側の要因が取り上げられてき た。個人側の要因としては, 科学志向, 専門職志向 (Pelz \& Andrews, 1966), 独立, 自律（Lorsch \& Morse, 1974）などがあげられる。また組織側の要因と しては，仕事自体の面白さ（Myers, 1964; Cherniss, 1991; 村杉, 1987; 太田, 1993)，仕事を遂行する上での 自律性 (autonomy) (Kornhauser, 1962; Lorsch \& Morse, 1974; Hall, 1975, Kerr, Von Gilnow \& Schriesheim; 1977, 加護野, 1984: 日本生産性本部, 1989; 太田，1993），専門的能力を蓄積する機会 （Cherniss, 1991; 日本生産性本部, 1989; 太田, 1993) が取り上げられている。しかし，これらの要因がどのよ うなメカニズムでプロフェッショナル・コミットメント を高まるのかについてはまだ明らかにされてない。

プロフェッショナル・コミットメントと業績との研究 で, 研究の数は少ないが一致していることは, プロフェッ ショナル・コミットメントが高ければ高い研究成果及び 業績をむたらすということである (Jauch, Glueck \& Osborn 1978; 蔡, 1997)。しかし，これらの研究は，ア カデミックな大学の研究者を対象にしており, 組織で働 くプロフェッショナルを対象にしてないという限界があ る。

プロフェッショナル・コミットメントと組織コミット 
メントは，並行し得ると主張したのは，Glaser（1963） である。彼は, アメリカの医学関連の研究所で働く研究 者を対象に実証研究を行った結果, プロフェッショナル。 コミットメントと組織コミットメントの両方とも高い研 究者グループが, 動機付けのレベルが最も高いと報告し ている。その後の多くの報告によると, 組織とプロフェッ ショナルの両方のコミットメントの間には相関がかなり 強く, 二重のコミットメントが成立すると結論付けてい る (Pelz \& Andrews, 1966; Delbecq \& Elfner, 1970; Miller \& Wager, 1981; Schroeder \& Imdieke, 1977; Wallace, 1993; Baugh \& Roberts, 1994)。

二重コミットメントと業績との関係についての研究で は，まだ議論の余地が多く残されている。Jauch, Glueck \& Osborn (1978) と蔡（1997）は，大学の研 究者を対象に調査を行い, 組織とプロフェッショナル両 方のコミットメントが強いメンバーのアカデミックな業 績は必ずしあ高くないとの結果を報告している。一方, Baugh \& Roberts（1994）と三崎（1998）は, 研究者・ 技術者を対象にした研究で, 二重コミットメントが業績 に及ぼす正の影響を与えていることを確認している。従っ て, 企業組織の中で働くプロフェッショナルを対象にし た二重コミットメントと業績に関して, 今までの研究は 必ずしる一貫した結果が主張されているわけではない。

二重コミットメントに関する先行研究における問題点 として, 大きく二つ指摘できる。第 1 は, 先行研究の多 くが二重コミットメントの可能性を示唆する研究ばかり
で，その規定要因に関してほとんど研究がなされていな いこと，また二重コミットメントがもたらす結果につい ても一貫していないことである。第 2 は, 研究対象がほ とんど看護婦, 公認会計士, 大学の教授など専門職組織 で働くプロフェッショナルであることである。企業の研 究開発従事者を対象とした研究むみられるが，事務系小 ワイトカラーを対象にした研究はほとんどない。

そこで, 本研究では, 事務系ホワイトカラーのコミッ トメントの規定要因は何か, また組織コミットメント, プロフェッショナル・コミットメント, 二重コミットメ ントと業績, 定着意志とのかかわりはどうなのかについ て調べていくことを主な目的とする。ここで二重コミッ トメントとは, 組織コミットメントあ高く, プロフェッ ショナル・コミットメントも高いこととして定義づける。 事務系ホワイトカラーの中には, 組織コミットメントが 高い人材と, プロフェッショナル・コミットメントが高 い人材がいることを想定し，それぞれ人材タイプ別にコ ミットメントの結果要因について比較していくことにす る。従って, 図1のような分析モデルを設計した。

\section{方 法}

\section{調査対象}

調査対象者は，民間企業13社に勤務するホワイトカラー 正社員である。2000年 7 月から 9 月までに, 関東と関西 の企業従業員305名に質問紙調査を実施した。有効解答 は180であった（有効回答回収率59\%)。回答者の性別は,

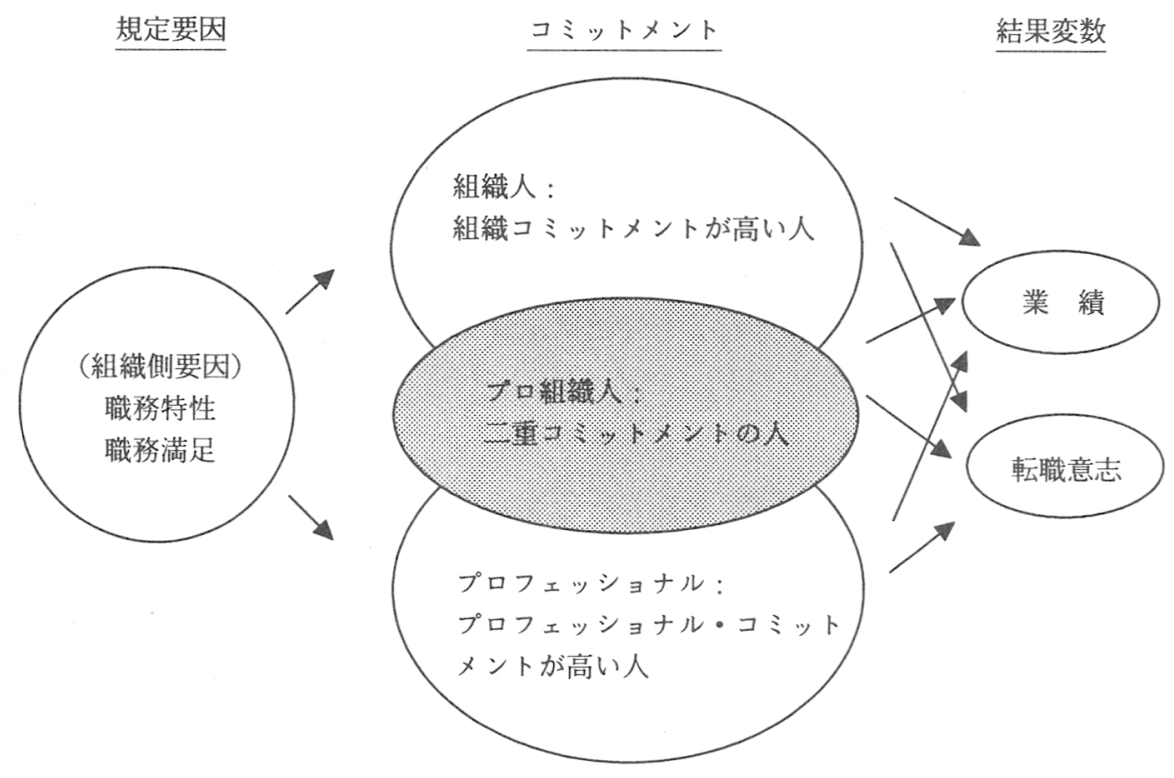

図1 分析モデル 
男性144, 女性34, 無回答2である。年齢は30代か $56.1 \%$, 40 代が $26.8 \%, 50$ 代が $16.8 \%$ である。学歴は, 大卒が73. $7 \%$, 大学院卒が $7.3 \%$ である。平均勤続年数は 16.1 年で ある。企業の業種の内訳は，製造業が $43 \% ，$ 非製造業が $57 \%$ 占めている。

\section{尺 度}

本研究では探索的分析を行うため, 組織コミットメン トならびにプロフェッショナル・コミットメントの規定 要因である組織側要因について多様な項目を採用した。

(1) 職務特性については, Hackman \& Oldham （1976）の職務特性モデルを一部修正した 8 の質 問項目（仕事の多様性，仕事の完結性，仕事の創 造性, 仕事の専門性, 仕事の重要性, 仕事のフィー ドバック, 仕事の進め方の自律性, 目標設定の自 律性）によって測定した。

(2) 職務満足については, MSQ（ミネン夕満足測定 尺度, Weiss et al., 1967, p.3.）を一部修正した 7 の質問項目（給与及び金銭的報酬に関する満足, 昇進機会に関する満足, 上司に関する満足, 同僚 に関する満足, 仕事に関する満足, 専門知識や技 術の習得機会に関する満足, 会社の政策や経営方 針に関する満足）によって測定した。

(3) プロフェッショナル・コミットメントの規定要 因として, 日本生産性本部 (1989), Cherniss (1991)，太田（1993），三崎（1998）によって共 通で取り上げられた組織側の要因を一部修正した 9 の質問項目（高度の専門知識を求める職務, 仕 事を通じた社会への貢献, 専門知識や技術習得, 大学院への派遣など最先端技術の習得, 研修など 社内での能力開発, 社外での研究会への参加, キャ リアのコース転換, 専門を軸にしたジョブ・ロー テーション，個人のプランに合わせた教育訓練） によって測定した。

(4) 組織コミットメントに関しては Porter, Steers, Mowday, et al. (1974) の OCQ 尺度を一部修 正し，12の質問項目によって測定した $(\alpha=.89)$ 。

(5) プロフェッショナル・コミットメントは, OCQ 尺度がとらえる対象を組織から専門分野に変えて, 12 の質問項目によって测定した $(\alpha=.87)$ 。ここ で専門分野についての質問内容は,「あなたが最 あ精通し，自信を持っておられる専門分野につい てお伺います」というふうに記述した。回答者は 事務系ホワイトカラーに限定されており, 専門分 野を自分が経験した職種（営業, 経営企画, 情報 処理, 海外事業, 経理・財務など）の中で一つを
想定し，回答している。それぞれの項目が自分に 当てはまるかどうかについて，6段階で評定を求 めた。

プロフェッショナル・コミットメントと組織コ ミットメントの平均点を基準に高・低に分け, 四 つのグループを構成した。高組織コミットメント かつ高プロフェッショナル・コミットメント $(n=54)$ のグループをプロ組織人と呼ぶ。プロ 組織人とは, プロフェッショナルと組織人を合成 した造語である。本稿でプロ組織人とは, 組織と 専門性両方に対するコミットメントが高い人とし て, 二重コミットメントをする人として見なす。 二重コミットメントについては, 組織コミットメ ントとプロフェッショナル・コミットメント両方 の平均点が高いグループを二重コミットメントを 行なっているグループと見なす。高組織コミット メントかつ低プロフェッショナル・コミットメン ト $(n=41)$ のグループを組織人と呼ぶ。低組織 コミットメントかつ高プロフェッショナル・コミッ トメント $(n=27)$ のグループをプロフェッショ ナルと呼ぶ。そして, 低組織コミットメントかつ 低プロフェッショナル・コミットメント $(n=58)$ のグループを周辺人と呼ぶ。分析にあ たっては, 組織コミットメント, プロフェッショ ナル・コミットメント, 二重コミットメントが比 較対象として設定される。

(6) 各コミットメントがあたらす結果要因を測定する ために, 業績に関しては, 担当職務の前年度の目 標達成度を採用した。

(7) 転職意志に関しては,「あなたは今の会社で働き 始めてから真剣に転職したいと考えたことがあり ますか」と、「あなたは今の会社より理想的な仕 事や給与が与えられるのであれば，他の会社に転 職したいと思いますか」という二つの項目で測定 した $(\alpha=.61)$ 。

本調査では上述の項目について， 6 件法のリカート尺 度を用いて測定している。

\section{結 果}

組織コミットメントならびにプロフェッショナル・コ ミットメントを規定する要因を探索するために, 主因子 解による因子分析を行った。その結果, 6因子が抽出さ れた。バリマックス回転後の因子負荷量は表 1 に示すと おりである。

第 1 因子に高い負荷を表す項目には, 「仕事の多様性 $(\lambda=.73)\rfloor$, 「仕事の創造性 $(\lambda=.71)\rfloor$, 「仕事の専門 
表 1 全サンプルの規定要因に関する因子分析結果

\begin{tabular}{|c|c|c|c|c|c|c|}
\hline 因 & 第 1 & 第 2 & 第 3 & 第 4 & 第 5 & 共通性 \\
\hline 仕事の多様性 & .73 & -.13 & .04 & .22 & -.05 & .60 \\
\hline 仕事の創造性 & .71 & .22 & .03 & .09 & .11 & .58 \\
\hline 仕事の専門性 & .80 & .06 & -.03 & .07 & -.03 & .64 \\
\hline 仕事の重要性 & .68 & .12 & .11 & .08 & .24 & .55 \\
\hline 仕事に関する満足 & .68 & -.07 & .41 & .21 & -.18 & .71 \\
\hline 専門知識や技術習得に関する満足 & .65 & -.08 & .41 & .08 & -.30 & .70 \\
\hline 仕事のフィードバック & .61 & .21 & .09 & -.02 & -.12 & .44 \\
\hline 仕事の進め方に関する自律性 & .59 & .17 & .05 & .28 & .28 & .53 \\
\hline 大学院への派遣など最先端技術の習得 & -.09 & .62 & .47 & .07 & -.01 & .61 \\
\hline 研修など社内での能力開発 & .08 & .74 & .36 & -.02 & -.11 & .70 \\
\hline 社外での研究会への参加 & .18 & .74 & .16 & -.02 & -.14 & .63 \\
\hline 給料及び金銭的報酬に関する満足 & .02 & .14 & .69 & .12 & .16 & .53 \\
\hline 会社の政策や経営方針に関する満足 & .08 & .17 & .68 & .23 & .11 & .56 \\
\hline 昇進機会に関する満足 & .11 & -.14 & .77 & .04 & .19 & .66 \\
\hline キャリアのコース転換 & .05 & .13 & .07 & .66 & -.35 & .58 \\
\hline 専門を軸にしたジョブ・ローテーション & .11 & .18 & -.10 & .73 & .12 & .60 \\
\hline 個人のプランに合わせた教育訓練 & .17 & .45 & -.01 & .62 & .10 & .62 \\
\hline 同僚に関する満足 & .15 & .02 & .07 & -.08 & .79 & .73 \\
\hline 上司に関する満足 & .20 & .21 & -.01 & .09 & .83 & .71 \\
\hline 固有値 & 5.77 & 2.79 & 1.44 & 1.14 & 1.11 & \\
\hline 寄与率(\%) & 28.83 & 13.93 & 7.21 & 5.72 & 5.57 & \\
\hline
\end{tabular}

性 $(\lambda=.80)\rfloor$,「仕事の重要性 $(\lambda=.68)\rfloor$,「仕事に関 する満足 $(\lambda=.68)\rfloor$, 「専門知識や技術習得に関する満 足 $(\lambda=.65)$, 「仕事のフィードバック $(\lambda=.61) 」$, 「仕事の進め方に関する自律性 $(\lambda=.59) 」$ といった項 目が含まれた。これらの項目で共通に表れる特性は, 仕 事自体が高度な専門知識や技術を要求し, 仕事を遂行す ることが社会的に重要な意味を持ち, 個人の専門能力が さらに開発できることとして考えられる。そこで，ここ ではこの因子を「職務上の専門性」と名づけることにす る。

第 2 因子に高い負荷を表す項目には, 「大学院への派 遣など最先端技術の習得 $(\lambda=.62)$, 「研修など社内で の能力開発 $(\lambda=.74)$, 「社外での研究会への参加 $(\lambda=$. 74)」といった項目が含まれていた。最先端技術の習得, 研修, 社外研究会への参加などの構成項目から推察する と,「研修を通じた能力開発」を意味する因子というこ とができる。

第 3 因子に高い負荷を表す項目には，「給料及び金銭 的報酬に関する満足 $(\lambda=.69)$ 」「会社の政策や経営方 針に関する満足 $(\lambda=.68)\rfloor$, 「昇進機会に関する満足 $(\lambda=.77) 」 と い っ た$ 項目が含まれていた。いずれも仕 事の内容そのものの面白さややりがいからくる達成感や 充実感について満足というょりは，仕事以外のあのであ
る，給料や会社の政策，昇進機会などによる満足である。 ここではこの因子を，「外在的満足」と名づけることに する。

第 4 因子に高い負荷を表す項目には,「キャリアのコー ス転換（ $\lambda=.66) 」$,「専門を軸にしたジョブ・ローテー ション $(\lambda=.73)\rfloor$,「個人のプランに合わせた教育訓練 $(\lambda=.62) 」 と い っ た$ 項目が含まれていた。これは, 個 人が長期的な視点から組織との相互作用を通じて自分自 身の計画に基づいてキャリアを開発し，管理していくこ とを意味する因子であることから，「キャリア開発」と 名づけることにする。

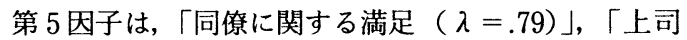

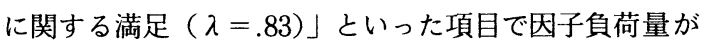
高く，「人間関係への満足」を意味する因子と言えょう。

因子分析の結果, 各因子ごとに測定された変数の平均 值を利用し, 規定要因と各コミットメントが業績と転職 意志に影響を及ぼすというモデルを検証するために，重 回帰分析を行い，その結果を表 2 で表した。その結果, 以下の点が明らかになった。

まず, 表 2 の左闌に示されているように業績を従属変 数とした本研究のモデルが有意であることが明らかになっ た。業績に対する各变数の貢献度を見るために, 標準化 
ホワイトカラーの二重コミットメントが業績と転職意志に及ぼす影響

表 2 業績と転職意志を従属变数とした重回帰分析

\begin{tabular}{|c|c|c|}
\hline \multirow[b]{2}{*}{ 規定要因（因子） } & \multicolumn{2}{|c|}{ 従 属 変 数 } \\
\hline & 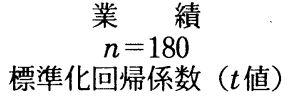 & $\begin{array}{c}\text { 転職意志 } \\
n=180 \\
\text { 標準化回㷌係数 }(t \text { 値 })\end{array}$ \\
\hline 職務上の専門性 & $.24(2.50)^{*}$ & $.05(.58)$ \\
\hline 研修の通じた能力開発 & $.11(1.25)$ & $-.01(-.16)$ \\
\hline 外在的満足 & $.03(.27)$ & $.20(2.01)^{*}$ \\
\hline キャリア開発 & $.22(2.50)^{* *}$ & $.09(1.02)$ \\
\hline 人間関係への満足 & $-.20(-2.22) *$ & $.00(.01)$ \\
\hline 二重コミットメント & $.09(.81)$ & $.23(2.67)^{* *}$ \\
\hline 組織コミットメント & $.01(.21)$ & $.22(2.10)^{*}$ \\
\hline プロエッショナル・コミットメント & $.04(.36)$ & $-.09(-1.09)$ \\
\hline 自由度修正済み決定係数 & .15 & .20 \\
\hline $\mathrm{F}$ 値, 自由度 $(8,171)$ & $4.84^{*}$ & $6.55^{*}$ \\
\hline
\end{tabular}

${ }^{*} p<.05 \quad p<.01$

回帰係数を検討すると,「職務の専門性」( $\beta=.24, p<$

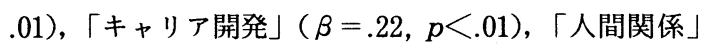
$(\beta=-.20, p<.01)$ が有意に業績と関連した。この結 果から, 職務の専門性とキャリア開発が「業績」に正の 影響を及ぼすが, 良い人間関係が「業績」とは負の関係 があることが統計的に実証された。また，業績に対する コミットメントの貢献度は, 標準化回州係数を検討する

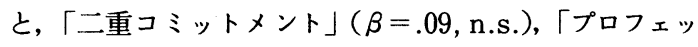
ショナル・コミットメント」( $\beta=.04$, n.s. $)$,「組織コ ミットメント」( $\beta=.01$, n.s. $)$ であり, すべて統計的 に有意ではなかった。

続いて, 表 2 の右闌に示されているように転職意志を 従属変数とした本研究のモデルが有意であることが明ら かになった。転職意志に対する各変数の貢献度を見るた めに, 標準化回帰係数を検討すると,「外在的満足」( $\beta=$ $.20, p<.05)$, 「二重コミットメント」 $(\beta=.23, p<.01)$, 「組織コミットメント」（ $\beta=.22, p<.05)$ が転職意志 に有意な関連性をむっている。この結果から, 外在的満 足が「転職意志」の低下に正の影響を及ぼすことが統計 的に実証された。また「二重コミットメント」と「組織 コミットメント」が「転職意志」の低下に影響を及ぼす が, プロフェッショナル・コミットメントは「転職意志」 に影響しないことが明らかとなった。

以上の結果から，プロ組織人と組織人が，プロフェッ ショナルと周辺人に比べて業績には影響しないが, 転職 意志を低减する効果が高いことが確認された。

\section{結論と今後の研究課題}

今回の研究では, 事務系ホワイトカラーのコミットメ ントの現実を把握するために, 組織コミットメント, プ
ロフェッショナル・コミットメント, 二重コミットメン ト理論に従い, 分析モデルを構築し, 実証研究を行った。 分析の結果は, 次の四つの点で示唆を含んでいた。

第 1 に，業績に有意な影響を与える要因は，職務自体 があつ専門性, 個人のプランに合わせたキャリア開発で あることが明確となった。つまり，個人に新しいアイデ ア, 創造性, 専門性, イノベーション能力を引き出せる ような職務が与えられ，また個人が自らの責任でキャリ アを開発し，組織側が最大限サポートすることが，業績 を上げる原因となることが示唆される。つづいて，業績 への影響に関して特に注目すべき点は, 従来の日本企業 の特徵として重視されてきた上司と仲間とのよい人間関 係が，業績には負の影響を与えているということである。 このことは, 最近日本企業において成果主義や能力主義 の導入により，自分の成果のみを追及することが優先と なり，同僚を助けたりすることが，かえって自分の業績 が低下してしまう可能性を示唆する。

第 2 に, 各コミットメントの違いは業績に有意に影響 を与えていないことが分かった。この結果は, コミット メントが職場の有効性変数である業績を高めるだろうと いう予想は，支持されない結果となった。その理由とし て，業績の測定自体が非常に難しいことを取り上げる。 今回の調査で使用した業績の測定に関しても, 個人にとっ て前年度の業績目標の達成度について主観的に回答させ たため，十分な客観的基準で測定できなかったかもしれ ない。従って, 次回の研究では, より客観的なデー夕を あとに評価できるような調査をする必要がある。

第 3 に，外在的満足，すなわち，企業から与えられる 高い給与, 良い会社の政策, 昇進機会への満足が, 継続 して働きつづけたい意志につながることが確認された。 
このことから, 従来日本企業の情意考課に慣れた人たち が, 成果主義の導入によって自分の評価が下がってしま うと, 転職志向へ向かう可能性が高いということがいえ る。以上のように考えれば, 現在多くの企業で導入して いる成果主義が企業の有効性にいかに結びつくかについ てさらなる検証が必要であろう。

第 4 に, 今回の研究の発見点は, 二重コミットメント と組織コミットメントが転職意志を低くすることに影響 を与えていることが明確になったことである。つまり， 従来日本企業の特徴として組織コミットメントが高けれ ば, 当然組織に残って働きつづけたい傾向が強いと知ら れてきたが, 二重コミットメントが高い場合も, 組織に 残りつづけたい傾向が強いことを示している。これらの 結果から推察できることは, 事務系ホワイトカラーにお いて, 従来のような高い組織コミットメントが求められ ていれば，それに加えてプロフェッショナル・コミット メントが求められても, 彼らは他の企業に転職しないと いうことである。つまり, 組織コミットメントの高さが キーとなっている。

最後に今回の調査の限界として取り上げられることは, 社員個人に対して, どの対象にどの程度コミットメント しているかを測定したので, 組織側が必要とするコミッ トメントの対象, 人材に対しては調査しなかったことで ある。従って, 次回の研究では, 企業の人事担当者を対 象にした調査やインタビューを通じて, 実際に企業で求 める人材について詳しく調査を実施する必要がある。

\section{引用文献}

Allen, N.J. \& Meyer, J.P. 1990 The measurement and antecedents of affective, continuance and normative commitment to the organization. Journal of Occupational Psychology, 63, 118.

Aranya, N. \& Ferris, K. R. 1984 A reexamination of accountants' organizational professional conflict. The Accounting Review, 59, 1-15.

Aranya, N., Pollock, J, \& Amernic, J. 1981 An examination of professional commitment in public accounting. Accounting, Organizations and Society, 6, 271-280.

Baugh, S. G. \& Roberts, R.M. 1994 Professional and organizational commitment among engineers: comflicting or complementing?. IEEE Transactions on Engineering
Management , 41(2), 108-114.

Beck, K \& Wilson, C. 2000 Development of affective organizational commitment: A crosssequential examination of change with tenure. Journal of Vocational Behavior, 56, 114-136.

Brett, J.F., Cron, W.L. \& Slocum, J.W. 1995 Economic dependency on work: A moderator of the relationship between organizational commitment and performance. Academy of Management Journal, 38, 261-271.

Buchanan, B. 1974 Building organizational commitment; The socialization of managers in work organizations. Administrative Science Quarterly, 19, 533-546.

蔡仁錫 1997 プロフェッショナル組織における戦略的人 的資源管理 慶應義塾大学大学院商学研究科博士学 位論文.

Cherniss, C. 1991 Career commitment in human service professionals: A biographical study. Human Relations, 44(5), 419-437.

Delbecq, A.L. \& Elfner, E.S. 1970 Localcosmopolitan orientations and career strategies for specialists. Academy of Management Journal, 13, 373-387.

Dunhum, R.B., Grube, J.A. \& Castaneda, M.B. 1994 Organizational commitment: The utility of an integrative definition. Journal of Applied Psychology, 79, 370-380.

富士ゼロックス総合教育研究所 1997 '97 人材開発白書.

Glaser. B.G. 1963 The Local-cosmopolitan scientist. American Journal of Sociology, 69, 249-259.

Hackman, J.R. \& Oldman, G.R. 1976 Motivation through the design of work: Test of a theory. Organizational Behavior and Human Performance, 16, 250-279.

Hall, R.H. 1975 Occupations and the social structure. Prentice-Hall.

花田光世 1980 日本的経営における従業員の帰属意識一 現実と研究水準の狭間で一. 産業能率大学研究所季 報, 5, 2-13.

石倉洋子 1995 企業内プロフェッショナリズムを活かす システム. DIAMONDハーバード・ビジネス, 4 , 47-55.

Jauch, L.R., Glueck, W.F. \& Osnorn, R.N. 1978 Organizational loyalty, professional commit- 
ment, and academic research productivity. Academy of Management Journal, 21,84-92.

加護野忠男 1984 研究開発組織における因果モデルの共 有と社会的相互作用. 国民経済雑誌, 神戸大学, 149(4), 19-37.

Kerr, S., Von Gilnow, M.A. \& Schriesheim, J. 1977 Issues in the study of professionals in organizations: The case scientists and engineers. Organizational Behavior and Human Performance, 18, 329-345.

城戸康彰 1980 日本企業における組織コミットメント. 三田商学研究 23(3), 132-151.

Kornhauser, W. 1962 Scientists in industry: Conflict and accommodation. Berkeley and Los Angeles: University of California Press.

Lachman, R., \& Aranya, N. 1986 Job attitudes and turnover intentions among professionals in different work setting, Organization Studies, 7, 279-293.

Lee, S.M. 1971 An empirical analysis of organizational identification. Academy of Management Journal, 14, 213-226.

Lorsch, J.W., \& Morse, J.J. 1974 Organizations and their members: A contingency approach. New York: Harper \& Row. (馬場昌雄・服部 正中・上村祐一訳 組織・環境・個人 東京教学社 1977).

Maslow, A.H. 1954 Motivation and Personality (2nd ed.) New York: Harper \& Row（小口忠 彦訳 (改正新版) 人間性の心理学 産能大学出版部 1987).

Mathieu, J.E. \& Hamel, K. 1989 A causal model of the antecedents of organizational commitment among professionals and no professionals. Journal of Vocational Behavior, 34 , 299-317.

Mathieu, J.E. \& Zajac, D.M. 1990 A review and meta-analysis of the antecedents, correlates, and consequences of organizational commitment. Psychological Bulletin, 108, 171-194.

Miller, G.A., \& Wager, L.W. 1981 Adult socialization, organizational structure, and role orientations. Administrative Science Quarterly, 16, 151-163.

三崎秀夫 1998 研究開発従事者の準拠集団, 業績, モチ ベーターペイント業界における研究職, 技術職, 技
術サービス職の比較一。経営行動科学, 12(2), 89-102.

Morris J, \& Sherman, J.D. 1981 Generalizability of an organizational commitment model. Academy of Management Journal, 24, 512526.

Morrison, E.W. 1994 Role definitions and organizational citizenship behavior: The importance of the employee's perspective. Academy of Management Journal, 37, 1543-1567.

Morrow, P.C., \& Wirth, R.E. 1989 Work commitment among salaried professionals. Journal of Vocational Behavior, 34, 40-65.

Mowday, R.T., Porter, L.W. \& Dubin, R. 1974 Unit performance, situational factors, and employee attitudes in spatially separated work units. Organizational Behavior and Human Performance, 12, 231-248.

Mowday, R.T., Steers, R.M. \& Porter, L.W. 1979 The measurement of organizational commitment. Journal of Vocational Behavior, 14, 224-247.

村杉健 1987 作業組織の行動科学 税務経理協会.

Myers, M.S. 1964 Who are your motivated workers. Harvard Business Review, 42(1), 73-88.

日本生産性本部生産性上級技術者問題研究委員会 1989 研究開発技術者のキャリアと能力開発.

西田豊昭 2000 職務満足, 組織コミットメント, 組織公 正性, OCBが職場の有効性に及ぼす影響. 経営行 動科学, 13(3), 137-158.

ニッセイ基礎研究所 2000 グローバル化時代の専門人材 の育成に向けて一金融機関の専門人材育成を中心に一.

太田肇 1993 プロフェッショナルと組織一組織と個人の 間接的統合一同文舘.

O'Reilly, C. \& Caldwell, D.F. 1981 The commitment and job tenure of new employees: some evidence of postdecisional justification. $A d$ ministrative Science Quarterly, 26, 597-616.

O'Reilly, C. \& Chatman, J. 1986 Organizational commitment and psychological attachment: The effects of compliance, identification, and internalization on prosocial behavior. Journal of Applied Psychology, 71, 492-499.

Pelz, D.C., \& Andrews, F.M. 1966 Scientists in organization, Wiley (兼子宙監訳 創造の行動科 学ダイヤモンド社 1971). 
Porter, L.W., Crampon, W.J. \& Smith, F.J. 1976 Organizational commitment and managerial turnover: A longitudinal study. Organizational Behavior and Human Performance, 15, 87-98.

Porter, L.W., Steers, R.M., Mowday, R.T. \& Boulian, P.V. 1974 Organizational commitment, job satisfaction, and turnover among psychiatric technicians. Journal of Applied Psychology, 59, 603-609.

Schroeder, R.G. \& Imdieke, L.F. 1977 Localcosmopolitan and bureaucratic perceptions in public accounting firms. Accounting, Organization and Society, 2, 1-10.

Steers, R.M. 1977 Antecedents and outcomes of organizational commitment. Administrative Science Quarterly, 22, 46-56.

Stevens, S.M., Beyer, J.M. \& Trice, H.M. 1978 Assessing personal role, and organizational predictors of managerial commitment. Academy of Management Journal, 20, 207-228.
田尾・高木・益田・石田・唐沢編 1997 会社人間の研究一 組織コミットメントの理論と実態. 京都大学学術出 版会.

高木・石田・益田 1997 実証的研究一会社人間をめぐる 要因構造（田尾・高木・益田・石田・唐沢編 会社 人間の研究一組織コミットメントの理論と実態. 京 都大学学術出版会.

若林満 1986 組織コミットメントの年齢別・企業規模別 比較. 労務学会年報, 29-41.

Wallace, J. E. 1993 Professionals and organizational commitment: compatible of incompatible. Journal of Vocational Behavior, 42, 333-349.

Weiss, D.R., Dawis, G. England \& L.Lofquist, 1967 Manual for the Minnesota Satisfaction Questionnaire, Minnesota Studies in Vocational Rehabilitation, X X II .

Wiener, Y. 1982 Commitment in organization: A normative view. Academy of Management Review, 7, 418-428.

(平成12年12月 8 日受稿. 平成13年 3 月 30 日受理) 